International Journal of Current Advanced Research

ISSN: O: 2319-6475, ISSN: P: 2319 - 6505, Impact Factor: SJIF: 5.995

Available Online at www.journalijcar.org

Volume 6; Issue 4; April 2017; Page No. 3209-3210

DOI: http://dx.doi.org/10.24327/ijcar.2017.3210.0227

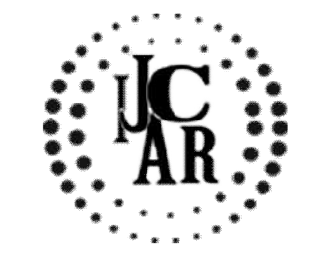

Research Article

\title{
THE ROLE OF PERSONALITY'S MEANING WORK IN COPING WITH TRAUMATIC EXPERIENCE
}

\author{
Olga Magomed-Eminova*
}

Department of Psychological Help and Resocialization, Moscow State University, Russian Federation

\begin{tabular}{|c|c|}
\hline A R T I C L E I N F O & A B S T R A C T \\
\hline Article History: & In present study the influence of personality meaning work on successful coping with \\
\hline $\begin{array}{l}\text { Received } 29^{\text {th }} \text { January, } 2017 \\
\text { Received in revised form } 10^{\text {th }} \text { February, } 2017 \\
\text { Accepted } 22^{\text {nd }} \text { March, } 2017 \\
\text { Published online } 28^{\text {th }} \text { April, } 2017\end{array}$ & $\begin{array}{l}\text { traumatic experience is examined. In research and formulating hypotheses, the authors } \\
\text { stand on provisions of meaning-activity approach to studying personality reactions to } \\
\text { traumatic events. The basis of study challenges with traditional negative dealing with } \\
\text { consequences of traumatic events that have grown out of medical paradigm. Traumatic } \\
\text { experience is seen here as extraordinary event that becomes the source of growth of }\end{array}$ \\
\hline Key words: & $\begin{array}{l}\text { coping with traumatic experience and post-traumatic growth with positive personality } \\
\text { meaning work. }\end{array}$ \\
\hline
\end{tabular}

experience, posttraumatic growth, traumatic

event, activity-meaning approach.

Copyright $₫ 2017$ Olga Magomed-Eminova. This is an open access article distributed under the Creative Commons Attribution License, which

permits unrestricted use, distribution, and reproduction in any medium, provided the original work is properly cited.

\section{INTRODUCTION}

In a dynamic modern world, various kinds of extreme situations, such as loss, trauma, illness, natural and man-made disasters, wars, conflicts, terrorist attacks, etc., are rapidly invading human life, as well as an increasing amount of information about all that kind of events from the media. In such circumstances of existence, a contemporary person progressively encounters (meets) with extreme, traumatic experience in his life which inevitably becomes a part of his existence. In the psychological literature, despite the recent appeal of a number of domestic and foreign authors to study the positive impact of traumatic experience, the negative attitude toward the consequences of stress, crisis, conflict, trauma, loss, not to mention disasters, catastrophes, terrorist attacs, etc. - still dominates.

The history of the negative approach in the study of the psychological consequences of a trauma originates in the medical paradigm and is based on the isolation and description of disorders caused by traumatic stress (Lindemann E., 1984; Freud Z, 1984). The traumatic tradition of treating the consequences of an accident (the doctrine of traumatic neurosis) arose in the works of E.Eriksheyn, A.Page, Moely, H.Oppenheim, J.-M.Charcot, and further developed in the studies of Jeanne, as well as J.Breyer and S.Freud. Since then, and up to date, extreme, extraordinary situations have been denoted by very different terms in the psychological literature: they are called "traumatic",

*Corresponding author: Olga Magomed-Eminova Department of Psychological Help and Resocialization, Moscow State University, Russian Federation "critical", "catastrophic", "difficult life situations", "extreme conditions" or factors. However, in spite of terminology variety most psychological studies have similarities identifying extreme (traumatic) situation. Usually factors are called extremal when have a tendency to impose heightened, limiting demands to human activities, stressors that worsen the working capacity of a person, undermining health, causing posttraumatic reactions and disorders (Magomed-Eminov M.Sh., 2009, 2014).

However, modern studies of the psychological reactions of victims of traumatic events gradually reveal (expose) not only negative, but also positive effects of trauma on the individual - that is, not only the disorder and adaptation become the consequences of extreme situations, but there are copulation and adaptation, as well as -Post-Traumatic Growth phenomenon (Tedeschi R.G., 2004; Foa E., Keane T., Friedman M., 2009; Stroebe M.S. , 2005). In modern studies, the period after trauma is seen as a stage in which the meaning work of personality is carried out, as well as positive, transgressive processes for the individual (Magomed-Eminov M.Sh., 1998, 2007). A person strengthens his hope and self- confidence and trying to diminish negative sets and states. Traumatic experience here is seen as a source of positive personality changes, growth and development of a person. In the activity-meaning approach, developed by M.Sh.Magomed-Eminov, an extreme situation is regarded as an extraordinary event in the life of a person, the reaction to which acquires the meaning of a psychological fact, when in the course of mental work a person can change its status. 


\section{MATERIALS AND METHODS}

We conducted the study aimed at revealing the influence of meaning work of a person on successful coping with traumatic experience. We assumed that a positive perception of the world, a focus on life-centered meanings, directly correlates with successful coping with traumatic experiences and the emergence of post-traumatic growth. 84 people (58 men and 26 women aged 24 to 62 years) who survived the traumatic event performed as subjects. During the research, the following methods were used: "Posttraumatic Growth Inventory" (PTGI) by R.Tedeschi, L.Calhoun (translated and adapted in Russian by M.Sh.Magomed-Eminov) and "Unfinished sentences" J.Nutten (translated and adapted in Russian by M.Sh.Magomed-Eminov).

\section{RESULTS}

According to the data obtained from the scores by PTGI technique, we identified two groups of subjects. In group 1 posttraumatic growth after trauma was identified. In group 2 posttraumatic growth was not detected.

As a result of the content analysis of the methodology "Uncompleted sentences", we allocated two groups of statements: positive and negative. Statements were identified as negative by the categories: negative images, indicating a lack of meaning in life, reflecting a greatly reduced (low) selfesteem, containing pessimistic thoughts. Positive statements were those containing positive images, reflecting the confidence of the subjects in themselves, hopes for better, optimistic thoughts. The priority of positive statements $(48 \%$ in PTG group and $8 \%$ in non-PTG group) associated with high scores of posttraumatic growth, negative personal statements (26\% in non-PTG group and $12 \%$ in PTG group) with low scores on PTG - or absence of post-traumatic growth.

Table 1 Distribution of positive and negative statements

\begin{tabular}{ccc}
\hline & Group 1 & Group 2 \\
\hline $\begin{array}{c}\text { Positive } \\
\text { statements } \\
\begin{array}{c}\text { Negative } \\
\text { statements }\end{array}\end{array}$ & $48 \%$ & $8 \%$ \\
\hline
\end{tabular}

Table 2 gives examples of positive and negative statements of post-traumatic experience.

Table 2 Positive and negative statements

\begin{tabular}{|c|c|}
\hline Positive statements & Negative statements \\
\hline I hope for happiness and peace & I fear to die in poverty \\
\hline $\begin{array}{l}\text { I hope everything will be the way } \\
\text { I want }\end{array}$ & I'm afraid of death \\
\hline I hope to live in harmony & $\begin{array}{c}\text { When I think about the future, I do not } \\
\text { believe in it }\end{array}$ \\
\hline I hope my plans will come true & $\begin{array}{l}\text { Sometimes I think, that I lived in a wrong } \\
\text { way }\end{array}$ \\
\hline $\begin{array}{l}\text { I dream to live in harmony with } \\
\text { myself }\end{array}$ & Sometimes it seems, this will not remain \\
\hline $\begin{array}{l}\text { I hope that everything will be } \\
\text { fine }\end{array}$ & $\begin{array}{l}\text { Sometimes it seems that I can never live } \\
\text { well }\end{array}$ \\
\hline I hope that everything is formed & Sometimes it seems to me that I'm useless \\
\hline $\begin{array}{l}\text { I think that everything will be } \\
\text { fine }\end{array}$ & $\begin{array}{c}\text { Sometimes it seems to me that I'm a } \\
\text { nonentity }\end{array}$ \\
\hline Everything will be fine & $\begin{array}{c}\text { Sometimes it seems to me that I'm in } \\
\text { despair }\end{array}$ \\
\hline I hope for the best & $\begin{array}{c}\text { Sometimes it seems I can no longer stand } \\
\text { being so exhausted }\end{array}$ \\
\hline
\end{tabular}

\section{DISCUSSION}

From the data given in Table 1, it can be seen that people, who have been diagnosed with posttraumatic personality growth are more likely to use statements that reflect a positive perception of the world, plans for the future, and hopes for the best. At the same time, people, whose posttraumatic growth was not identified are more likely to be concerned with fear, disbelief in the future, lack of hope, despair in their responses. The generalization of the obtained results allows us to conclude that the positive meaning work of the personality contributes to the successful coping and posttraumatic growth of the individual; While negative meaning work of the individual prevents effective coping and growth of the personality after trauma.

\section{CONCLUSIONS}

In modern revisions in psychology is becoming more and more evident, that extremity is a value-meaning phenomenon that is shaped in the meaning personality work with the ways of his existence, life in a shared (with the Other) world. Our research was aimed at studying the influence of meaning personality work on successful coping with traumatic experience and showed the direct dependence of post traumatic growth on the direction of the meaning work of the individual. The results of the research reveal the role of personality work in coping with trauma, and can also be used to develop methods for providing psychological assistance in a wide range of life situations.

\section{References}

1. Vasilyuk F.E. Understanding psychotherapy as a psychotechnical system: Dissertation on the doctor's degree. - M., 2007.

2. Lindemann E. Clinic of acute grief / Psychology of emotions. Texts / ed. By V.K.Vilyunas, Yu.B.Gippenreiter- Moscow State University, 1984.

3. Magomed-EminovM.Sh. Ontological conceptualization of the extremality phenomenon // Vestnik MGU. Series 14. Psychology. - 2014. - № 3. - P.79-91.

4. Magomed-EminovM.Sh. Phenomenon of Extremality // Bulletin of St. Petersburg State University. Series 12. Psychology. Sociology. Pedagogy. - 2010. - №1. Стр.28-38.

5. Magomed-EminovM.Sh. The activity- meaning approach to the psychological transformation of the personality: Dissertation on the doctor's degree Psychol. Sciences. M., 2009. - 570 pp.

6. Nutten J. Motivation, action and the prospect of the future / Ed. D.A.Leontiev / J. Nutten. - M.: Smysl, 2004.

7. Freud Z. Sadness and melancholy / Psychology of emotions. Texts/ed. byV.K.Vilyunas, Yu.B. Gippenreiter - Moscow State University, 1984.

8. Tedeschi R.G., Calhoun L.G. Posttraumatic growth: conceptual foundations and empirical evidence // Psychological Inquiry. - 2004. - 15(1). - P.1-18.

9. Foa E., Keane T., Friedman M. Effective Treatments for PTSD: Practice Guidelines from International Society for traumatic stress studies. 2-d ed. - NY: Guilford press, 2009.

10. Stroebe M.S. Attachment in Coping with Bereavement: a Theological Integration // Review of General Psychology. - 2005. - V.9(1). - P.48-66. 